\title{
ON APPLICATIONS OF INEQUALITIES FOR QUASIDEVIATION MEANS IN ACTUARIAL MATHEMATICS
}

\author{
JACEK CHUDZIAK
}

Abstract. Applying the results of Zs. Páles, concerning the inequalities for quasideviation means, we characterize some natural properties of implicitly defined functional stemming from actuarial mathematics.

Mathematics subject classification (2010): 39B22, 91B16.

Keywords and phrases: Quasideviation mean, zero utility principle, comparison, equality, positive homogeneity, subadditivity, convexity.

\section{REFERENCES}

[1] N. L. Bowers, H. U. Gerber, J. C. Hickman, D. A. Jones and C. J. Nesbitt, Actuarial Mathematics, The Society of Actuaries, Itasca Illinois, 1986.

[2] H. Bühlmann, Mathematical Models in Risk Theory, Springer, Berlin, 1970.

[3] Z. DARóCZY, A general inequality for means, Aequationes Math. 7 (1971), 16-21.

[4] Z. DARócZy, Über eine Klasse von Mittelwerten, Publ. Math. Debrecen 19 (1972), 211-217.

[5] Z. DarócZy ANd Zs. PÁles, On comparison of mean values, Publ. Math. Debrecen 29 (1982), $107-115$.

[6] H. U. Gerber, An Introduction to Mathematical Risk Theory, S. S. Huebner Foundation, Homewood Illinois: R. D. Irwin Inc., 1979.

[7] S. HEILPERN, A rank-dependent generalization of zero utility principle, Insurance: Mathematics and Economics 33 (2003), 67-73.

[8] M KaŁuszKa And M. KRZESzowiec, Pricing insurance contracts under Cumulative Prospect Theory, Insurance: Mathematics and Economics 50 (2012), 159-166.

[9] M. Kuczma, An Introduction to the Theory of Functional Equations and Inequalities, Birkhäuser, Berlin, 2009.

[10] L. LosonczI, General inequalities for nonsymmetric means, Aequationes Math. 9 (1973), 221-235.

[11] Zs. PÁLES, Characterization of quasideviation means, Acta. Math. Sci. Hungar. 40 (1982), 243-260.

[12] Zs. PÁLES, General inequalities for quasideviation means, Aequationes Math. 36 (1988), 32-56.

[13] S. T. Rachev, L. B. Klebanov, S. V. Stoyanov and F. J. Fabozzi, The Methods of Distances in the Theory of Probability and Statistics, Springer, New York, 2013.

[14] T. Rolski, H. Schmidli, V. Schmidt And J. Teugels, Stochastic Processes for Insurance and Finance, John Wiley \& Sons, New York, 1999. 